\title{
Assessing the Impact of the Retail Service Quality and In-Store Logistics on Customer Satisfaction and Loyalty
}

\author{
Moh Farid Najib ${ }^{1}$, Deddy Saefuloh ${ }^{2}$ \\ Department of Business Administration, Bandung State Polytechnic, Indonesia ${ }^{1,2}$ \\ \{mohfaridnajib@polban.ac.id $\left.{ }^{1}\right\}$
}

\begin{abstract}
Measuring service quality in the traditional markets to be very interesting, especially linked to in-store logistics, satisfaction, and loyalty of traditional markets customer. The purpose of this research is to analyze the influence of retail service quality and in-store logistics, on customer satisfaction and loyalty in the Indonesian traditional market context. The model proposed is to study the relationship between retail service quality and in-store logistics, satisfaction, and commitment. This research has been conducted on 400 customers in 16 traditional markets in West Java, Indonesia. A procedure of structural equation modeling has been applied to evaluate the proposed research model. The methodology used consists of two stages. The first step was to check the construct validity through Convergent Validity (CV), Average Variance Extracted (AVE), Construct Reliability (CR), and Discriminant Validity (DC). Secondly, structural equation modeling. The results reveal that retail service quality has positively influenced loyalty, however, they show a non-significant effect on customer satisfaction. On the other hand, in-store logistics have positively influenced customer satisfaction, but not customer loyalty. Furthermore, satisfaction also positively influences loyalty.
\end{abstract}

Keywords: Retail Service Quality, In-Store Logistics, Satisfaction, Loyalty

\section{Introduction}

The measurement scale for retail has been developed based on the SERVPERF scale which consists of five dimensions with 28 items [1]. This measurement scale model has been extensively researched in the context of modern markets such as supermarkets [2], [3], however research in the context of traditional markets is still rarely done. Traders in traditional markets still consider the factor of price, product, and promotion as competitive advantage sources, but they ignore the potential in creating value for the customer through in-store logistics [4]. Overcoming some of the challenges of change in traditionally designed supply chains such as; information, infrastructure, processes, and culture, is very difficult [5]. Rapid changes in the retail industry today have made it more difficult to attract buyers' attention and handle the competition [6]. Meanwhile, research in retail logistics is still rarely done [7], [8]. 
Some research has been carried out on the relationship between customer satisfaction on retail service performance, however, in terms of retail logistics performance factor and its effect on consumers is still infrequent [9]. To remain in a very competitive market, retailers need to improve their performances on supply chain operations [10]. Customer experience will determine substantially their level of satisfaction [11]. These factors are empirically proven to explain the relationship with customer satisfaction [12], [13]. Likewise, customer loyalty is a significant factor in achieving retail businesses' success and increasing their market share. Customer loyalty does not only create customer recalling, but it also generates customers' suggestions about the stores to their colleagues [14]. Service quality affects the customer satisfaction level [15], [16]. High-quality service will produce a high customer satisfaction level and increase loyalty [13], [17]. Customer satisfaction is a factor that strongly determines customer loyalty [18]. Meanwhile, in-store logistics also plays a central role in satisfaction and loyalty [4]. Therefore, this paper aims to measure the influence of retail service quality (RSQ) and in-store logistics on satisfaction and loyalty in the context of Indonesian traditional markets.

\section{Theoretical Background}

The concept of service quality has been pursued, including that it is a linkage of overall service excellence with attitude assessment [15]. Nevertheless, the general parameters used to evaluate service quality may not be appropriate in the context of the retail industry [19]. Therefore, empirically, the RSQ scale has been developed and validated [1]. The RSQ has been implemented in measuring the quality of delivery services at department stores [14]. Validation of the RSQS implementation has been carried out in retail businesses in Korea and the USA [20], and in traditional markets in Indonesia [21].

The RSQ consist of; physical aspects (store appearance and layout), reliability (keeping their promises and do the right things), personal interaction (polite, helpful, and stimulate confidence), problem-solving (capability of personnel in handling returns and exchanges, problems and complaint of the customer), policies (quality merchandise, credit/debit cards, operating hours, and parking) [1]. However, from the validity results, the measurement model for retail service quality in the context of traditional markets uses four dimensions, namely; physical aspects, personal interactions, appointments, and problem-solving [21]. Other studies have shown that three dimensions (physical aspects, reliability, and problem-solving) have a significant positive effect on service quality [21]. However, the personal interaction dimension shows a significant negative effect, while the policy dimension does not have a significant effect on service quality [22].

In-store logistics are strongly perceived in all efficient and disciplined logistics management operations at the point of sale [23]. Therefore, the in-store logistics performance will create value for the store by influencing prospective customers to produce more value [4]. In-store logistics is focused on all flow processes in store-based retail outlets. Outlets are locations of transactions/exchanges for trading products, of course, payments also occur. Therefore, in the retail business, the activity that plays a big role is product availability, because if the product is not available, there will be no purchase transaction [24]. In-store logistics operations consist of handling, managing, ordering, and processing merchandise in the store [25]. The operation of in-store logistics is essential in influencing the customer experience. Convenience factors in retail stores surface from customers' experience when getting into and leaving a computer memory, as well as naming and accessing the product 
promptly and easily. The store layout design is significant in parliamentary procedure to make customers move easily inside stores [26]. Effective stock-outs and shelf management are the first experience for customers and is called the "first moment of truth" [4], [27].

The information displayed in the stores influences a customer's impression of retail service. Therefore, by providing the right information, customers can make better purchasing decisions [28], [29], allowing them to obtain a higher value. Customers recognize that the store usually provides information and know-how the store handles complaints. The convenience of shopping is an important aspect, and the shopping experience facilities can have an inappropriate influence on customers' perceptions of the store [30]. Completeness of shopping aids, such as; adequate packaging/wrapping and shopping baskets and additional lines and waiting times related to customers leaving the store, become experiences for the customers [31]. Customers also care about returns [1], the product they bought that returned to retailers [32]. The conclusion from the above discussion suggests that the higher the customer perception of service quality, the higher their satisfaction and loyalty. Likewise, the higher the perception of in-store logistics, the higher their satisfaction and loyalty. Therefore, the hypothesis we have developed are:

$\mathrm{H}_{.1}$ : Traditional retail service quality has a positive effect on customer satisfaction significantly

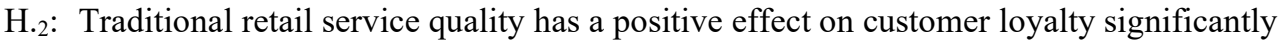

$\mathrm{H}_{3}$ : In-store logistics of the traditional market has a positive effect on customer satisfaction significantly

H.4: In-store logistics of the traditional market has a significant effect on customer loyalty

Satisfaction refers to consumers' responses to product offers and the gap between the perceived and expected performance of a product [33]. Explicitly, service satisfaction generates a special service experience [34], [35]. Satisfaction generates from various factors of the quality and value that are perceived by customers, as nature is the element of human character, and customers will compare their experiences with other experiences of the service in another place to come up with much better future decisions [4]. Satisfaction inclines to produce from overall evaluations of various aspects that shape relationships of the customer and are not solely the result of certain transactions with providers [36].

Satisfaction and loyalty have a relationship by which loyal customers will always be satisfied as without such feeling they will not come again. Researchers argue that satisfaction is behind the reason for customer retention in every retail store [37]. Loyalty determines how much effort to provide the best service to customers and to maintain them [38]. Emotional attachment is also a factor to form customer loyalty to a particular store [4]. Loyalty is a factor that keeps a business operating as a form of guarantee of sales by several customers, so customer loyalty is the main sought-after factor to be transformed from their shopping experiences [37]. We believe that the higher the satisfaction of traditional market customers, the higher their loyalty, thus we formulate the following hypothesis:

H.5: Customer satisfaction of the traditional market has a significant effect on customer loyalty

\section{Methodology}

The survey instrument was developed in four variables, namely; RSQ, in-store logistics, satisfaction, and loyalty. First, The retail service quality measurement scale uses five dimensions (physical aspects, reliability, personal interaction, problem-solving, and policy) [1] 
Second, the scale of the in-store logistics refers to the scale adopted and modified to measure four dimensions, namely, stock, return shopping aid, and product attributes [4]. Third, the customer satisfaction scale was adopted and modified from previous studies [13], [34]. Fourth, likewise for customer loyalty is adopted and modified from previous studies [13], [34].

The data were collected using a one-shot/cross-sectional time horizon because this research was only conducted once. The time which is one shot / cross-sectional means that the data or information collected is the result of research conducted within a certain period [39]. The sample size is 400 respondents who shop from 16 traditional marketplaces in West Java, Indonesia.

\section{Result and Discussion}

\subsection{Measurement Model}

The principle of the measurement model is to show how the manifest variables / observed variables represent the latent constructs to be measured. Construct validity indicates confidence when the indicator / sub-indicator measure taken from the sample represents the real score in the population. Construct validity is evaluated based on Convergent Validity, Average Variance Extracted, Construct Reliability, and Discriminant Validity.

Table 1. Measurement Model

\begin{tabular}{|c|c|c|c|c|}
\hline $\begin{array}{l}\text { Dimensions / Sub- } \\
\text { dimensions }\end{array}$ & $\begin{array}{l}\text { Loading } \\
\text { Factor }\end{array}$ & $\begin{array}{c}\text { Average } \\
\text { Variance } \\
\text { Extracted }\end{array}$ & $\begin{array}{l}\text { Construct } \\
\text { Reliability }\end{array}$ & $\begin{array}{c}\text { Discriminant } \\
\text { Validity }\end{array}$ \\
\hline $\begin{array}{l}\text { Retail Service Quality } \\
\text { Physical Aspect }\end{array}$ & & 0,583 & 0,901 & 0,764 \\
\hline PA4 & 0,859 & 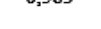 & 0,301 & 8,704 \\
\hline PA3 & 0,916 & & & \\
\hline PA2 & 0,600 & & & \\
\hline & 0,629 & & & \\
\hline Personal Interaction & & 0,762 & 0,923 & 0,873 \\
\hline PI4 & 0,890 & & & \\
\hline $\begin{array}{c}\text { PI3 } \\
\text { Promises }\end{array}$ & 0,855 & 0,835 & 0,975 & 0,914 \\
\hline PR4 & 0,911 & & & \\
\hline PR3 & 0,927 & & & \\
\hline PR2 & 0,935 & & & \\
\hline PR1 & 0,881 & & & \\
\hline Problem Solving & & 0,791 & 0,955 & 0,889 \\
\hline $\mathrm{PS} 3$ & 0,917 & & & \\
\hline PS2 & 0,918 & & & \\
\hline \multirow{2}{*}{\multicolumn{5}{|c|}{ In-Store Logistics }} \\
\hline & & & & \\
\hline${ }_{\text {Sto } 2}$ & & 0,742 & 0,915 & 0,862 \\
\hline $\begin{array}{l}\text { SS2 } \\
\text { SS1 }\end{array}$ & $\begin{array}{l}0,867 \\
0,856\end{array}$ & & & \\
\hline Return & & 0,834 & 0,950 & 0,913 \\
\hline RT2 & 0,880 & & & \\
\hline $\begin{array}{c}\text { RT1 } \\
\text { Shopping Aid }\end{array}$ & 0,945 & & & \\
\hline $\begin{array}{l}\text { Shopping Aid } \\
\text { SC4 }\end{array}$ & & 0,709 & 0,945 & 0,842 \\
\hline $\begin{array}{l}\text { SC4 } \\
\text { SC3 }\end{array}$ & $\begin{array}{l}0,758 \\
0,750\end{array}$ & & & \\
\hline $\mathrm{SC} 2$ & 0,911 & & & \\
\hline $\mathrm{SC} 1$ & 0,933 & & & \\
\hline Product & & 0,675 & 0,876 & 0,822 \\
\hline $\begin{array}{l}\text { PT2 } \\
\text { PT1 }\end{array}$ & 0,929 & & & \\
\hline $\begin{array}{c}\text { PT1 } \\
\text { Information }\end{array}$ & & 0,699 & 0,637 & 0,836 \\
\hline INF4 & 0,680 & & & \\
\hline \multicolumn{3}{|l|}{$\begin{array}{r}\text { INF1 } \\
\text { Satisfaction }\end{array}$} & 0,975 & 0,881 \\
\hline SF6 & 0,865 & 0,770 & & \\
\hline SF5 & 0,904 & & & \\
\hline SF4 & 0,844 & & & \\
\hline SF3 & 0,885 & & & \\
\hline$\underset{\mathrm{SF} 2}{\mathrm{SF}}$ & 0,885 & & & \\
\hline \multicolumn{5}{|l|}{$\begin{array}{l}\text { SF1 } \\
\text { Loyalty }\end{array}$} \\
\hline $\begin{array}{l}\text { Loyalty } \\
\text { LOY5 }\end{array}$ & 0,902 & 0,795 & & \\
\hline LOY 4 & 0,947 & & & \\
\hline LOY3 & 0,955 & & & \\
\hline LOY2 & 0,939 & & & \\
\hline LOY1 & 0,897 & & & \\
\hline
\end{tabular}


The results of construct validity as shown in table 1 describe four types, namely, loading factor, average variance extracted (AVE), construct reliability (CR), and discriminant validity (DC). The loading factor shows the coefficient that explains the level of relationship between the indicator and the latent variable. Convergent validity is measured by loading factor values and it is a construct indicator that must be convergent or share the variance proportion. The standard output of the loading factors explains that all loading factors are above 0.5 (see Table 1). The standard loading estimate of at least 0.50 [40]. The loading factor at least 0.30 if the sample size 350 respondents [41]. This concludes that the loading factor is statistically significant, as it is higher than 0.50 .

In the confirmatory factor analysis, construct validity meets the AVE criteria> 0.50 [40], as the loading factor is higher than 0.70 which means this shows good convergence. The results tell that most AVE of retail service quality, in-store logistics, satisfaction, and loyalty are higher than 0.5 (see Table 1). The construct reliability coefficient must be more than 0.70 and the reliability is good., while the reliability of $0.6-0.7$ is still acceptable [40]. The results of the construct reliability are shown in Table 1 which shows that all dimensions / subdimensions are above 0.7 , while the value of the construct reliability for dimensions / subdimensions is below 0.7 (information 0.637), but still acceptable [40].

\subsection{Structural Equation Model (SEM)}

The structural equation model integrates exogenous and endogenous latent variables or combines the relationship between exogenous variables and other endogenous variables.

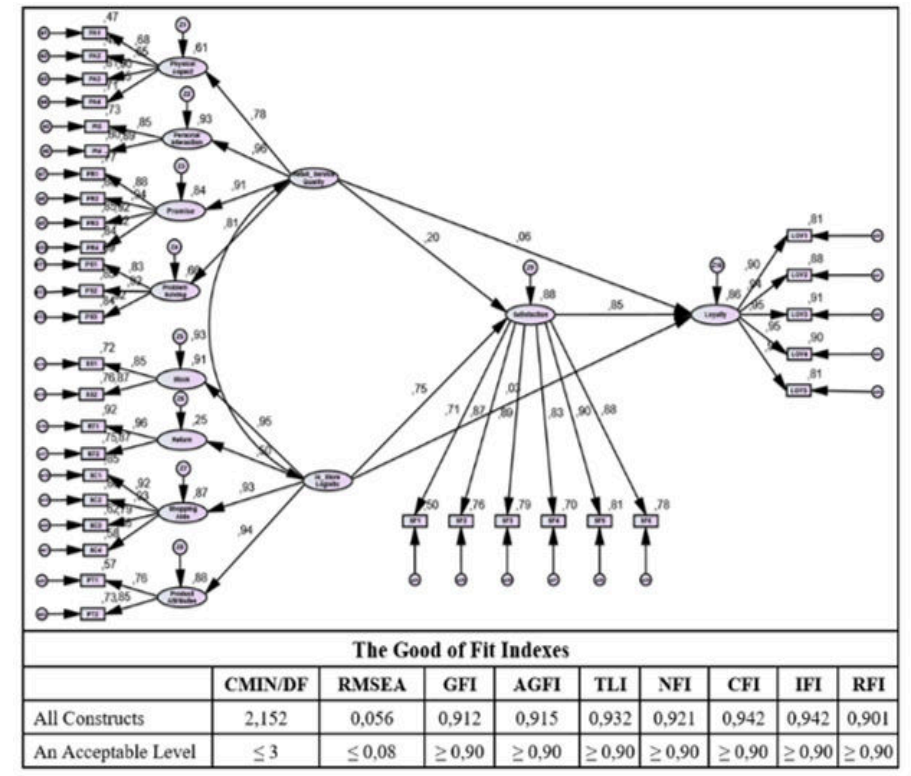

Fig. 1. Structural Equation Model

The structural equation model shows an excellent model (see Figure 1), with CMIN / DF results of 2.152, as well as, other Goods of fit indexes have a value of more than $90 \%$ which indicates a very good model, as RMSEA value of 0.056 is below 0 . 
The study's purpose was to analyze the effect of traditional retail service quality, in-store logistics, customer satisfaction, and loyalty. Figure 1 and Table 2 show the influence of the variables (retail service quality, in-store logistics, customer satisfaction, and customer loyalty).

Table 2. Hypothesis Testing Result

\begin{tabular}{lcccccc}
\hline \multicolumn{1}{c}{ Hypothesis } & $\begin{array}{c}\text { Stand } \\
(\text { Est) }\end{array}$ & SE & CR & P-Value & Result \\
\hline $\mathrm{H}_{1}$ Retail Service Quality $\longrightarrow$ Customer Satisfaction & .075 & .124 & .610 & .015 & Rejected \\
$\mathrm{H}_{2}$ Retail Service Quality $\longrightarrow$ Customer Loyalty & .264 & .136 & 3.948 & $* * *$ & Accepted \\
$\mathrm{H}_{3}$ In-Store Logistics $\longrightarrow$ Customer Satisfaction & .031 & .143 & .217 & .828 & Rejected \\
$\mathrm{H}_{4}$ In-Store Logistics $\longrightarrow$ Customer Loyalty & .820 & .115 & 7.140 & $* * *$ & Accepted \\
$\mathrm{H}_{5}$ Customer Satisfaction $\longrightarrow$ Customer Loyalty & .865 & .103 & 8.382 & $* * *$ & Accepted \\
\hline Stand. Est (Standardized Estimated) & & & & &
\end{tabular}

SEM outputs shown in Table 2, states that the first hypothesis, namely retail service quality of traditional market significantly impacts on the satisfaction of the customer and shows that the critical ratio (CR) of .610 for retail service quality association to customer satisfaction and the P-value (probability) of 0.051 is not significant by default. In other words, the regression weight for customer satisfaction is not significantly predicted by retail service quality. Therefore, it can be concluded that retail service quality has no significant effect on customer satisfaction. Thus, the findings of this study are different from research conducted by [1], [20], [42]. This condition is caused particularly by the condition of Indonesian traditional markets, which are perceived as muddy, smelly, cramped, and a lot of waste which causes customers to be dissatisfied with traditional market services.

However, in the second hypothesis, i.e. the quality of retail service in the traditional market significantly impacts the customer loyalty and shows that the critical ratio (CR) is 3,948 for retail service quality associated with customer loyalty, and the P-value (probability) *** which means it is significant by default. In other words, the regression weight for customer loyalty is predicted by retail service quality significantly. These findings support the findings of [13], [17], [18], this condition occurs because customers still think that the completeness of the products sold in traditional markets is relatively complete, prices are relatively cheaper, products are fresher and the market opens from the morning. While the third hypothesis: The in-store logistics of the traditional market impacts significantly on the customer satisfaction and shows that the critical ratio (CR) is .217 for the in-store logistics association with customer loyalty, and the P-value (probability) .828 which means not significant by default. In other words, the regression weight for customer satisfaction is not predicted by in-store logistics significantly. The level of customer satisfaction related to in-store logistics is still low, this is indicated by the aspects of convenience and shopping facilities in traditional markets, which are still perceived as low by customers, while Van-Riel et al, [35] stated that the convenience and shopping facilities aspects can build customer perception of the shop. Improving the design, planning, and control of in-store logistics operations can therefore improve customer perceptions of the store, this condition supports the estimation. In-store logistics directly contributes $85 \%$ to image retention. This shows that the buyer's perception of the shop's image in traditional markets is very dependent on the quality of in-store logistics. This finding is also shown by the better implementation of traditional market in-store logistics related to stock, returns, shopping assistance, product attributes, and information that can improve traditional market customer satisfaction. Thus, the findings of this study are different from those of [4] on research in supermarkets. 
The fourth hypothesis, namely customer perceptions of in-store logistics performance is related directly and positively to customer loyalty, resulting in the critical value (CR) 7,140 on the effect of customer satisfaction on customer loyalty, and also the P-value (probability) is significant***, with default. This means the regression weight for customer loyalty is predicted by in-store logistics significantly. It can be concluded that in-store logistics affects traditional market customer loyalty. Although traditional market customers are not satisfied with the performance of in-store logistics, on the contrary, traditional market customer loyalty shows the level of loyalty to traditional markets related to the performance of in-store logistics, this condition is because traditional markets can provide products that are still fresh, open from day to day, and interaction with traders is very close.

The final hypothesis is that the level of traditional market customer satisfaction is directly and positively related to customer loyalty. The result shows the critical value (CR) of 8,382 on the effect of customer satisfaction on customer loyalty, on the P-value (probability) significance with $* * *$ indicates significant by default. This means the regression weights for predicted customer loyalty. Thus, it can be concluded that traditional market consumer satisfaction in West Java, Indonesia directly gives $98 \%$ of consumer loyalty. This means that traditional market buyers have loyalty. The results of this study prove that customer satisfaction has a direct and positive relationship with customer loyalty. This finding supports the previous research [4], [21].

\section{Conclusions}

This study combines two research domains, namely, retail logistics, and marketing services. This paper is intended to increase understanding of the role of logistics in ensuring product availability in stores, particularly in traditional markets in Indonesia. How to handle in-store logistics starting from product availability, ease of return systems and tools available for shopping as well as information for customers about interactions with service scale can improve the development of in-store logistics strategies.

Increasing the competitiveness of traditional markets needs to be supported by improving the traditional market service quality through guaranteed product availability in stores. Instore logistics also relate to the ease of finding a kiosk location in terms of providing the best location information, as well as changing the image of traditional markets, which are associated with slums, stinking, and lots of garbage.

\section{References}

[1] P. A. Dabholkar, D. I. Thorpe, and J. O. Rentz, "A measure of service quality for retail stores: scale development and validation," J. Acad. Mark. Sci., vol. 24, no. 1, p. 3, 1996.

[2] A. Das, V. Kumar, and G. C. Saha, "Retail service quality in context of CIS countries," Int. J. Qual. Reliab. Manag., vol. 27, no. 6, pp. 658-683, 2010, doi: 10.1108/02656711011054542.

[3] M. F. Diallo and A. M. Seck, "How store service quality affects attitude toward store brands in emerging countries: Effects of brand cues and the cultural context," J. Bus. Res., 2018, doi: 10.1016/j.jbusres.2017.08.017.

[4] O. Bouzaabia, A. C. r. Van Riel, and J. Semeijn, "Managing in-store logistics: A fresh 
perspective on retail service," J. Serv. Manag., 2013, doi: $10.1108 / 09564231311323926$.

[5] S. S. Saghiri, M. Bernon, M. Bourlakis, and R. Wilding, "Omni-channel logistics special issue,” Int. J. Phys. Distrib. Logist. Manag., vol. 48, no. 4, pp. 362-364, 2018, doi: 10.1108/IJPDLM-05-2018-361.

[6] K. Willems, M. Brengman, and S. Van De Sanden, "International Journal of Retail \& Distribution Management For Authors In-store proximity marketing: experimenting with digital point-of-sales communication," Cornell Univ. Libr., vol. 1847, no. 18, pp. 47-10, 2017, [Online]. Available: https://doi.org/10.1108/IJRDM-10-2016-0177.

[7] J. Hong, A. T. H. Chin, and B. Liu, "Logistics outsourcing by manufacturers in China: a survey of the industry," Transp. J., pp. 17-25, 2004.

[8] A. M. Knemeyer, T. M. Corsi, and P. R. Murphy, "Logistics outsourcing relationships: customer perspectives," J. Bus. Logist., vol. 24, no. 1, pp. 77-109, 2003.

[9] A. Namin, "Revisiting customers' perception of service quality in fast food restaurants," J. Retail. Consum. Serv., vol. 34, pp. 70-81, 2017.

[10] Estampe, D., Lamouri, S., Paris, J.L. and Brahim-Djelloul, S., "A framework for analysing supply chain performance evaluation models," Int. J. Prod. Econ., vol. 142, no. 2, pp. 247-258, 2013, doi: https://doi.org/10.1016/j.jipe.2010.11.024.

[11] S. Grzeskowiak, J. Sirgy, T. Foscht, and B. Swoboda, "Article information : Linking retailing experiences with life satisfaction: The concept of store-type congruity with shopper' s identity Introduction Shopping motivation is one of the key constructs of research on shopping behaviour. It is," Int. J. Retail Distrib. Manag., vol. 44, no. 2, pp. 124-138, 2016.

[12] Z. Yang and R. T. Peterson, "Customer perceived value, satisfaction, and loyalty: The role of switching costs," Psychol. Mark., vol. 21, no. 10, pp. 799-822, 2004, doi: 10.1002/mar.20030.

[13] M. F. Najib and A. Sosianika, "Retail service quality, satisfaction, and trust: The key to shopper loyalty in the context of the Indonesian traditional market," Int. J. Electron. Mark. Retail., vol. 10, no. 4, 2019, doi: 10.1504/IJEMR.2019.104216.

[14] N. Y. M. Siu, N. Y. M. Siu, and J. T. Cheung, "A measure of retail service quality A measure of retail service quality," no. MARCH 2001, pp. 88-96, 2015.

[15] A. Parasuraman, L. L. Berry, and V. A. Zeithaml, "Refinement and reassessment of the SERVQUAL scale," J. Retail., vol. 67, no. 4, p. 420, 1991.

[16] H. Naeem, A. Akram, and M. I. Saif, "Service Quality and its impact on Customer Satisfaction: An empirical evidence from the Pakistani banking sector," Int. Bus. Econ. Res. J., vol. 8, no. 12, 2009.

[17] M. Kumar, F. T. Kee, and A. T. Manshor, "Determining the relative importance of critical factors in delivering service quality of banks," Manag. Serv. Qual. An Int. J., vol. 19, no. 2, pp. 211-228, 2009.

[18] Y. Y. Cheng, C.C., Chiu, S.I., Hu, H.Y. \& Chang, "A study on Exploring the Relationship Between Customer and Loyalty in the Fast-Food Industry: With Relationship Inertia as a Mediator5118-5126.," African J. Bus. Manag., vol. 5, no. 13, pp. 5118-5126, 2011, doi: https://doi.org/10.5897/AJBM10.870.

[19] G. Arun Kumar, S. J. Manjunath, and H. Naveen Kumar, "A study of retail service quality in organized retailing," Int. J. Eng. Manag. Sci., vol. 3, no. 3, pp. 370-372, 2012.

[20] S. Kim and B. Jin, "Validating the retail service quality scale for US and Korean customers of discount stores: An exploratory study," J. Serv. Mark., vol. 16, no. 3, pp. 
223-237, 2002, doi: 10.1108/08876040210427218.

[21] M. F. Najib and A. Sosianika, "Retail service quality scale in the context of Indonesian traditional market," Int. J. Bus. Glob., vol. 21, no. 1, 2018, doi: 10.1504/IJBG.2018.094093.

[22] A. Zia, "Assessing the service quality of department store using RSQS An Empirical study of Albaha Region, Saudi Arabia," Rajagiri Manag. J., 2020, doi: 10.1108/ramj11-2019-0023.

[23] C. Mena, M. Bourlakis, C. Holweg, C. Teller, and H. Kotzab, "Unsaleable grocery products, their residual value and instore logistics," Int. J. Phys. Distrib. Logist. Manag., vol. 46, no. 6/7, pp. 634-658, 2016, doi: https://doi.org/10.1108/IJPDLM-112014-0285.

[24] H. Kotzab and C. Teller, "Development and empirical test of a grocery retail instore logistics model," British Food Journal. 2005, doi: 10.1108/00070700510610995.

[25] A. C. Mckinnon, D. Mendes, and M. Nababteh, "In-store logistics: an analysis of onshelf availability and stockout responses for three product groups," Int. J. Logist. Res. Appl., 2007, doi: 10.1080/13675560701478075.

[26] P. A. Titus and P. B. Everett, "The consumer retail search process: a conceptual model and research agenda," J. Acad. Mark. Sci., vol. 23, no. 2, p. 106, 1995.

[27] E. Nelson and S. Ellison, "Shelf promotion: in a shift, marketers beef up ad spending inside stores; funky displays and lighting, TV spots in Wal-Mart; unsettling Madison Avenue," Wall Str. J., p. A-1, 2005.

[28] J. Mentzer, D. Flint, and J. Kent, "Developing a logistics service quality scale," J. Bus. Logist., 1999.

[29] J. T. Mentzer, S. M. Rutner, and K. Matsuno, "Application of the means-end value hierarchy model to understanding logistics service value," Int. J. Phys. Distrib. Logist. Manag., vol. 27, no. 9-10, pp. 630-643, 1997, doi: 10.1108/09600039710188693.

[30] A. C. r. Van Riel, J. Semeijn, D. Ribbink, and Y. Bomert-Peters, "Waiting for service at the checkout: Negative emotional responses, store image and overall satisfaction," $J$. Serv. Manag., 2012, doi: 10.1108/09564231211226097.

[31] G. Silberer and S. Friedemann, "RFID-based tracking of shopping behaviour at the point of sale-possibilities and limitations," in European Retail Research, Springer, 2011, pp. 27-45.

[32] Dunne, M., Gable, M., and Gephardt, R., Retailing. West Publishing, Cincinnati, OH, 1992.

[33] D. K. Yoo and J. A. Park, "Perceived service quality," Int. J. Qual. Reliab. Manag., vol. 24, no. 9, pp. 908-926, 2007, doi: https://doi.org/10.1108/02656710710826180.

[34] R. L. Oliver, “Whence consumer loyalty?,” J. Mark., 1999, doi: 10.2307/1252099.

[35] E. Tsitskari, C. H. Antoniadis, and G. Costa, "Investigating the relationship among service quality, customer satisfaction and psychological commitment in Cyprian fitness centres," J. Phys. Educ. Sport, vol. 14, no. 4, p. 514, 2014.

[36] R. Thakur, "Understanding Customer Engagement and Loyalty: A Case of Mobile Devices for Shopping," J. Retail. Consum. Serv., vol. 32, pp. 151-163, 2016, doi: 10.1016/j.jretconser.2016.06.004.

[37] J. Kandampully, "Service management: The new paradigm in retailing," in Service Management: The New Paradigm in Retailing, vol. 9781461415, 2012, pp. 1-315.

[38] W. Irfan, D. A. Siddiqui, and W. Ahmed, "Creating and retaining customers: perspective from Pakistani small and medium retail stores," Int. J. Retail Distrib. Manag., vol. 47, no. 4, pp. 350-367, 2019, doi: 10.1108/IJRDM-03-2018-0045. 
[39] S. Cooper, D.R, and Schindler, Business Research Methods. 12th Edition. New York: McGraw-Hill/Irwin, 2010.

[40] I. Ghozali, Model Persamaan Structural, Konsep dan Aplikasi Dengan program AMOS 22.0. (Structural Equation Model, Concept and Application with AMOS 22.0 program. Semarang: UNDIP, 2014.

[41] C. B. Hair, JR., Anderson, R.E., Ronald, L.T, and William, Multivariate Data Analysis, 7th ed. London: Prentice-Hall International, Inc, 2010.

[42] N. Y. M. Siu and J. T. Cheung, "A measure of retail service quality," Mark. Intell. Plan., 2001. 